\title{
Prevalensi dan Intensitas Ektoparasit pada Ikan Gabus (Channa striata) dari Tangkapan Alam dan Budidaya
}

\author{
Bahruddin Salam dan Dewi Hidayati \\ Jurusan Biologi, Fakultas Matematikan dan Ilmu Pengetahuan Alam, Institut Teknologi Sepuluh Nopember \\ Jl. Arief Rahman Hakim, Surabaya 60111 Indonesia \\ e-mail: dewi_hidayati@ymail.com
}

\begin{abstract}
Abstrak-Penelitian ini bertujuan untuk memperoleh data jenis-jenis ektoparasit serta prevalensi (P) dan intensitas (I) ektoparasit pada ikan gabus dari tangkapan alam (TA) dan budidaya (BD). Sampel ektoparasit diambil dari ikan gabus tangkapan alam dan budidaya masingmasing 20 ekor dengan metode scraping (pengerokan) pada bagian kulit dan insang. Sampel ektoparasit ditampung pada cawan Petri dan ditambahkan buffer formalin $0,5 \%$, lalu dipindahkan ke botol plakon berlabel. Selanjutnya diamati menggunakan mikroskop OpticLab, serta dilakukan perhitungan prevalensi dan intensitas. Hasil pengamatan ditemukan 4 jenis ektoparasit, yaitu Oodinium sp. (P $T A=75 \%, P B D=70 \%$; [I TA=4.4, I $B D=8.3]$ ind. per ikan), Trichodinasp. (P TA=30\%, P BD=15\%; [I TA=1.3, I $B D=1]$ ind. per ikan), Ichthyophthirius multifiliis ( $P$ $T A=65 \%, \quad P B D=15 \%$; [I TA=1.61, I $B D=1.66]$ ind. per ikan), Epistylis sp. (P TA=50\% ; [I TA=1.6] ind. per ikan). Prevalensi ektoparasit ikan gabus $(C$. striata $)$ pada tangkapan alam lebih tinggi dibandingkan budidaya. Nilai prevalensi tersebut lebih dipengaruhi faktor abiotik berupa suhu yang menghambat perkembangan fase infektif parasit.
\end{abstract}

Kata Kunci-Ektoparasit, Ikan gabus (C. striata), Intensitas, Prevalensi.

\section{PENDAhuluan}

$I^{\prime}$ KAN gabus diketahui mengandung protein dan albumin yang sangat penting bagi kesehatan [1]. Periode 1998-2008 jumlah tangkapan ikan gabus dari perairan umum mengalami kenaikan rata-rata $2,75 \%$ per tahun, sementara produksi budidaya ikan gabus mengalami peningkatan sebesar 5.535 ton pada tahun 2008 [2]. Produksi ikan gabus di Provinsi Jawa Timur mencapai 1.037,6 ton pada tahun 2010 [3]. Oleh karena itu, potensi ikan gabus sebagai salah satu sumberdaya perikanan, perlu dikembangkan dan diteliti lebih lanjut biologisnya. Budidaya ikan gabus merupakan upaya untuk memenuhi permintaan kebutuhan ikan gabus yang semakin meningkat. Namun demikian, usaha budidaya tidak terlepas dari ancaman bebagai jenis penyakit, contohnya parasit [4].

Ektoparasit pada ikan umumnya golongan crustacea, cacing dan protozoa. Ektoparasit ini menginfeksi sirip, sisik, operkulum dan insang ikan [5]. Tingkat kematian infeksi ektoparasit yang tinggi dapat mengakibatkan kematian akut, yaitu mortalitas tanpa menunjukkan gejala terlebih dahulu [6][7]. Berdasarkan penelitian Umara [8] terdapat ektoparasit Trichodina sp. yang menginfeksi ikan gabus yang hidup bebas di irigasi Cot Balee desa Meunasah Manyang Lamlhom Kecamatan Lhoknga Aceh Besar.
Ektoparasit merupakan permasalahan klasik yang merugikan, namun belum mendapat perhatian yang baik. Pengetahuan tentang prevalensi dan intensitas ektoparasit pada ikan merupakan hal yang mendasar dan penting, karena jenis penyakit yang dapat berpotensi menjadi kendala pada unit budidaya. Tujuan penelitian ini adalah memperoleh data jenis-jenis ektoparasit pada ikan gabus (C. striata), serta memperoleh data prevalensi dan intensitas ektoparasit pada ikan gabus (C. striata) dari tangkapan alam dan budidaya.

\section{Metode Penelitian}

\section{A. Waktu dan Pelaksanaan}

Penelitian dilakukan pada bulan Mei-Oktober 2016. Pengambilan sampel ikan gabus (C. striata) di 2 lokasi, yaitu anak sungai di Porong, Sidoarjo (GPS : L $7^{\circ} 32^{\prime} 38.64^{\prime \prime S}$, B $112^{\circ} 42^{\prime} 33.32^{\prime \prime T}$ ) untuk tangkapan alam, dan Tambak Segara, Sedati, Juanda (GPS : $7^{\circ} 22^{\prime} 13.81$ "S, B $\left.112^{\circ} 47^{\prime} 52.79 " T\right)$ untuk budidaya. Selanjutnya, preparasi dilakukan di Laboratorium Zoologi dan Rekayasa Hewan Biologi ITS Surabaya.

\section{B. Pengambilan Sampel}

Pengambilan sampel ikan gabus (C. striata) dilakukan di 2 lokasi yaitu budidaya dan tangkapan alam. Variabel kualitas air yang diukur berupa suhu, $\mathrm{pH}$, dan salinitas pada air di lokasi pengambilan ikan.

\section{Preparasi Sampel}

Sampel ikan gabus diambil sebanyak 20 ekor ikan tangkapan alam dan 20 ekor ikan dari budidaya untuk dilakukan pengukuran morfometri. Pengambilan data berat tubuh ikan dilakukan dengan neraca analitik digital. Metode pemeriksaan ektoparasit pada ikan gabus dilakukan dengan metode scraping (pengerokan) kemudian dimasukkan botol plakon berlabel [9]. Pengerokan dilakukan pada bagian organ kulit atau permukaan tubuh. Hasil pengerokan tersebut diletakkan pada cawan Petri dan diberikan buffer formalin 0,5\%. Begitu pula dengan insang, setelah diambil dari ikan gabus, insang diletakkan pada cawan Petri, dilakukan pengerokan secara perlahan dengan pinset, kemudian dimasukkan kedalam botol plakon berlabel dan ditambahkan buffer formalin $0,5 \%$.

\section{Pengamatan dan Identifikasi}

Pengamatan dilakukan dengan pengambilan larutan hasil scraping dari kulit dan insang, masing-masing diteteskan pada sedwig rafter modifikasi. Pengamatan dibantu dengan alat mikroskop compound dengan 
perbesaran 100 kali yang terhubung dengan OptiLab. Identifikasi parasit menggunakan buku dan jurnal identifikasi parasit [10][11][12][13][14][15].

\section{E. Analisis Hasil Prevalensi dan Intensitas Ektoparasit}

Berdasarkan hasil jenis dan jumlah parasit, kemudian dianalisis secara deskriptif untuk dihitung prevalensi dan intensitas parasit dengan rumus sebagai berikut :

Prevalensi $=\frac{\text { Jumlah } \text { ikan yang terinfeksi parasit }}{\text { Jumlah sampel ikan yang diamati }} \times 100 \%$

Intensitas $=\frac{\text { Jumlah total parasit yang menginfeksi }}{\text { Jumlah sampel ikan yang terinfeksi }}$

\section{HASIL DAN DISKUSI}

\section{A. Hasil Pengukuran Kualitas Air}

Hasil analisis kualitas air di tempat pengambilan sampel ikan gabus baik tangkapan alam maupun tambak budidaya (Tabel 1), menunjukkan kisaran suhu, $\mathrm{pH}$, dan salinitas yang sesuai untuk kehidupan ikan gabus $(C$. striata) [17][18][19]. Namun demikian, bagi kehidupan ektoparasit, rentang suhu dan $\mathrm{pH}$ nya lebih sempit. Oleh karena itu perbedaan suhu dan $\mathrm{pH}$ di lokasi sampling berpotensi mempengaruhi kehidupan parasit. Faktor $\mathrm{pH}$, terutama temperatur sangat mempengaruhi perkembangan ektoparasit [20][21][22][23][24].

TABEL 1. KUALITAS AIR

\begin{tabular}{ccccc}
\hline \hline \multirow{2}{*}{ No. } & \multirow{3}{*}{ Parameter } & \multicolumn{2}{c}{ Lokasi } & Referensi \\
\cline { 3 - 4 } & & TA & BD & \\
\hline 1. & Suhu & $26^{\circ} \mathrm{C}$ & $30^{\circ} \mathrm{C}$ & $25-32^{\circ} \mathrm{C}[17]$. \\
2. & $\mathrm{pH}$ & 6,8 & 7,2 & $6,2-7,8[18]$. \\
3. & Salinitas & $0 \mathrm{ppt}$ & $0,3 \mathrm{ppt}$ & $0-0,5$ ppt $[19]$. \\
\hline \hline \multicolumn{7}{l}{ Keterangan : TA=Tangkapan Alam, BD=Budidaya }
\end{tabular}

B. Hasil Pengamatan Jenis-Jenis Ektoparasit Ikan Gabus (C. striata)

Berdasarkan hasil pengamatan diperoleh 4 jenis ektoparasit yaitu Oodinium sp., Trichodina sp., Ichthyophthirius multifiliis, dan Epistylis sp.
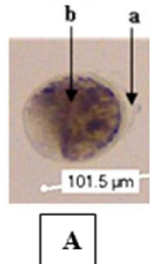
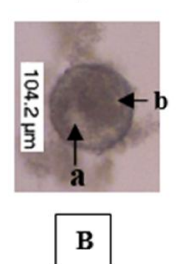
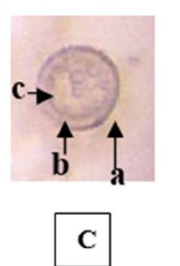

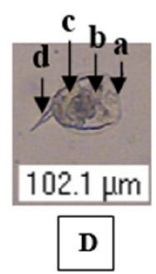

Gambar 1. Hasil pengamatan ektoparasit; [A] Oodinium sp. (a) Cakram perlekatan, (b) Sitoplasma. [B] I. multifiliis (a) Macronucleus, (b) Micronucleus. [C] Trichodina sp. (a) Zona adoral, (b) Membran, (c) Radial pin. [D] Epistylis sp. (a) Operculum, (b) Micronucleus, (c) Macronucleus, (d) Stalked.

1) Oodinium sp.

Oodinium sp. yang ditemukan memiliki bentuk oval dengan panjang $101.5 \mu \mathrm{m}$. Bentuk Oodinium adalah oval, sub-oval hingga fusiform dengan panjang $30-150 \mu \mathrm{m}$ [10][11][12]. Oodinium ditemukan dalam dua fase yaitu fase tropont, dengan ciri-ciri adanya juluran sitoplasma membentuk cakram perlekatan [12] dan fase mitosis, yang dicirikan dengan adanya segmentasi sel [10].

2) Ichthyophthirius multifiliis

I. multifiliis yang ditemukan memiliki bentuk bulat yang berukuran $104.2 \mu \mathrm{m}$, serta memiliki macronucleus dan micronucleus. I. multifiliis berbentuk bulat atau oval, yang berukuran \pm 50 -100 $\mu \mathrm{m}$, terdapat macronucleus dan micronuleus [13]. Parasit ini memiliki makronukleus berbentuk tapal kuda yang transparan dan mikronukleus yang menempel pada makronukleus [25].

3) Trichodina $s p$.

Trichodina sp. ditemukan memiliki bentuk bundar dengan ukuran $68,7 \mu \mathrm{m}$, dan memiliki bagian-bagian tubuh seperti radial pin, membran, dan zona adoral di bagian paling luar. Trichodina sp. berbentuk bundar dengan zona adoral [14]. Trichodina sp. tergolong parasit berbentuk bulat berukuran antara 50-90 $\mu \mathrm{m}$ [26].

4) Epistylis sp.

Epistylis sp. ditemukan memiliki bentuk tubuh seperti lonceng yang berukuran $102,1 \mu \mathrm{m}$, dengan bagian-bagian tubuh berupa operculum, macronucleus dan micronucleus, serta adanya stalked. Ciri-ciri Epistylis sp. memiliki operculum, terdapat macronucleus dan micronucleus, serta memiliki tangkai yang berfungsi sebagai alat penempel pada substrat inang [15]. Parasit ini berukuran 50-250 $\mu \mathrm{m}$, biasanya membentuk koloni dan tersusun pada tangkai [27].

C. Perbandingan Jenis, Prevalensi dan Intensitas Ektoparasit Ikan Gabus (C. striata) Tangkapan Alam dan Budidaya

TABEL 2. HASIL PREVALENSI DAN INTENSITAS EKTOPARASIT IKAN GABUS (C. STRIATA) PADA BUDIDAYA DAN TANGKAPAN ALAM

\begin{tabular}{ccccccc}
\hline \hline L & Ektoparasit & JSP & JSI & JE & P & I \\
\hline \multirow{4}{*}{ BD } & Oodinium sp. & 20 & 14 & 117 & $70 \%$ & 8,3 \\
& I. multifiliis & 20 & 3 & 5 & $15 \%$ & 1,66 \\
& Trichodina sp. & 20 & 3 & 3 & $15 \%$ & 1 \\
\hline \multirow{4}{*}{ TA } & Oodinium sp. & 20 & 15 & 64 & $75 \%$ & 4,2 \\
& I. multifiliis & 20 & 13 & 21 & $65 \%$ & 1,61 \\
& Trichodina sp. & 20 & 6 & 8 & $30 \%$ & 1,3 \\
& Epistylis sp. & 20 & 10 & 16 & $50 \%$ & 1,6 \\
\hline
\end{tabular}

Keterangan : $\mathrm{L}=$ Lokasi, $\mathrm{BD}=$ Budidaya, $\mathrm{TA}=\mathrm{T}$ angkapan Alam, JSP $=$ Jumlah Sampel Diperiksa, JSI $=$ Jumlah Sampel Terinfeksi, JE = Jumlah Ektoparasit, P = Prevalensi (\%), I = Intensitas (individu/ikan)

Hasil perhitungan nilai prevalensi menunjukkan bahwa individu dalam populasi ikan gabus (C. striata) dari alam lebih banyak terinfeksi ektoparasit dibandingkan dari budidaya. Perbandingan nilai prevalensi I. multifiliis antaraTA dan BD pada Tabel 2 menunjukkan selisih nilai prevalensi yang paling tinggi, yaitu $\mathrm{TA}=65 \%$ banding $\mathrm{BD}=15 \%$. Hal tersebut kemungkinan dipengaruhi faktor suhu, di mana suhu perairan lokasi sampel TA $\left(26^{\circ} \mathrm{C}\right)$ dan $\mathrm{BD}\left(30^{\circ} \mathrm{C}\right)$. Siklus hidup I.multifiliis sangat tergantung pada suhu, di mana pada suhu $30^{\circ} \mathrm{C}$ fase tomont I. multifiliis mengalami penghambatan pembelahan [9]. Pengendalian populasi parasit I.multifiliis dapat dilakukan dengan cara mempertahankan suhu pada $29-30^{\circ} \mathrm{C}$ [16]. Berdasarkan hal tersebut, air lokasi sampling BD yang menunjukkan suhu $30^{\circ} \mathrm{C}$ berpotensi menghambat perkembangan tomont I.multifiliis. Kondisi demikian dapat menyebabkan penurunan populasi pada tahap selanjutnya, yaitu tahap trophont (fase infektif), sehingga menurunkan penularan akibat menurunnya frekuensi interaksi antara hospes dengan fase infektif [28].

Trichodina sp. tumbuh subur di perairandengan rentang suhu air $25-30^{\circ} \mathrm{C}$ [29][30]. Semakin rendah temperatur akan meningkatkan prevalensi parasit pada ikan, di mana terjadi pertumbuhan optimum pada temperatur $21-26^{\circ} \mathrm{C}$ namun jika suhu bertambah tinggi (temperatur $27-32^{\circ} \mathrm{C}$ ) terjadi penurunan nilai prevalensi secara bertahap [31]. Berdasarkan hal tersebut, faktor 
suhu juga dimungkinkan menyebabkan prevalensi Trichodina sp. pada TA $\left(\mathrm{P}=30 \%\right.$, suhu $\left.26^{\circ} \mathrm{C}\right)$ lebih tinggi dibandingkan di perairan $\mathrm{BD}\left(\mathrm{P}=15 \%\right.$, suhu $\left.=30^{\circ} \mathrm{C}\right)$.

Epistylis sp. hanya ditemukan menginfeksi ikan gabus (C. striata) TA dengan nilai prevalensi $(\mathrm{P}=50 \%)$. Epistylis sp. dapat bereproduksi secara optimum pada perairan dengan suhu $10-25^{\circ} \mathrm{C}$ dan $\mathrm{pH} 6,5-7$ [32]. Hal tersebut dikarenakan faktor kualitas air di TA (suhu $26^{\circ} \mathrm{C}$ dan $\mathrm{pH}$ 6,8) lebih sesuai untuk pertumbuhan Epistylis sp. dibandingkan dengan di lokasi BD yang suhu dan $\mathrm{pH}$ nya lebih tinggi (suhu $30^{\circ} \mathrm{C}$ dan $\mathrm{pH} 7,2$ ).

Intensitas Oodinium sp. di $\mathrm{BD}(\mathrm{I}=8,3)$ lebih tinggi dibandingkan dengan TA $(\mathrm{I}=4,2)$. Hal tersebut mengindikasikan bahwa tiap individu ikan gabus $(C$. striata) pada BD terinfeksi lebih banyak ektoparasit Oodinium sp. dibandingkan dengan pada TA. Faktor yang bisa menyebabkan parasit berkembang pada ikan antara lain tejadinya kompetisi terhadap ruang dan perolehan makanan yang memicu terjadinya stres pada ikan [33][34]. Ikan yang stres dapat memicu terjadinya penyakit [35].

Parasit pada ikan sangat dipengaruhi oleh faktor abiotik dan biotik [24]. Berdasarkan penelitian ini dapat dinyatakan bahwa prevalensi ektoparasit pada ikan gabus (C. striata) lebih dipengaruhi faktor abiotik yaitu suhu yang menghambat perkembangan fase infektif parasit.

\section{Kelimpahan Ektoparasit Berdasarkan Organ Kulit dan Insang}

Ektoparasit yang ditemukan seperti Oodinium sp., Trichodina sp., I. multifiliis dan Epistylis sp. merupakan jenis-jenis ektoparasit yang biasa ditemukan di permukaan epitel kulit dan insang [36][37][32]. Berdasarkan kelimpahan ektoparasit yang ditunjukkan pada Gambar 2 dan Gambar 3, terlihat bahwa Oodinium sp. memiliki jumlah yang paling tinggi. Hal tersebut disebabkan Oodinium sp. membentuk koloni. Oodinium sp. merupakan parasit yang hidup berkoloni dan menyebabkan velvet disease pada ikan [38]. Selain itu, jika ditunjau secara keseluruhan, ektoparasit pada ikan gabus ( $C$. striata) lebih banyak ditemukan pada bagian organ kulit daripada insang, baik di lokasi budidaya maupun tangkapan alam.

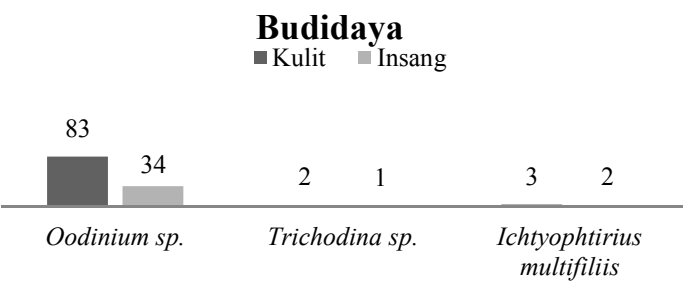

Gambar 2. Ektoparasit pada Ikan Gabus Budidaya

\section{Tangkapan Alam \\ - Kulit $\square$ Insang}

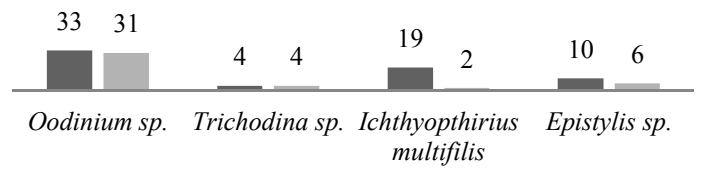

Gambar 3. Ektoparasit pada Ikan Gabus Tangkapan Alam

Parasit lebih mudah menempel pada organ kulit dibandingkan dengan insang yang sering tertutup oleh tutup insang (opercullum) [39][27]. Perilaku ikan gabus yang sering ditemukan hidup di dasar perairan[40], menyebabkan kemungkinan ektoparasit fase infektif yang menempel pada substrat mudah melakukan infeksi. Fase trophont parasit akan membentuk fase tomont yang akan menempel pada substrat di dasar perairan, selanjutnya tomont mengalami pembelahan secara aktif dan berubah menjadi stadia infektif theront [41].

Ikan gabus ( $C$. striata) merupakan jenis ikan yang mampu bernafas menggunakan oksigen dari udara (airbreathing fish) [42]. Ikan golongan tersebut dapat menggunakan air-breathing organ (ABO) untuk menyerap oksigen di udara dari atas permukaan air [43]. Adanya organ tersebut mengakibatkan organ insang pada ikan gabus tidak berkembang dengan baik. Chanidae termasuk air-breathing fish dan memiliki ruang suprabranchial yang kaya akan epitelium vascular sebagai ABO. Chanidae menunjukkan perkembangan ruang supra-branchial, yang menyebabkan tereduksinya organ insang [44].

Luas permukaan insang yang tereduksi pada ikan gabus, menyebabkan penurunan luas permukaan kontak dengan parasit, sehingga mengurangi kemungkinan parasit untuk menempel pada insang. Karena ukuran kulit yang lebih besar dari insang, sehingga semakin luas permukaan inang maka jumlah parasit juga akan bertambah banyak [39][27].

\section{KESIMPULAN}

Penelitian ini dapat disimpulkan bahwa nilai prevalensi ektoparasit pada ikan gabus (C. striata) dari lokasi tangkapan alam lebih tinggi dibandingkan pada lokasi budidaya, dan nilai intensitas ektoparasit Oodinium sp. pada ikan gabus (C. striata) lebih tinggi di lokasi budidaya dibandingkan dengan pada lokasi tangkapan alam. Prevalensi ektoparasit pada ikan gabus (C. striata) lebih dipengaruhi faktor abiotik yaitu suhu yang menghambat perkembangan fase infektif.

\section{UCAPAN TERIMA KASIH}

Terima kasih kepada Ibu Dr. Dewi Hidayati, M.Si., selaku dosen pembimbing tugas akhir yang telah memberikan bimbingan dan arahan serta dukungan. Terima kasih juga kepada orang tua, teman-teman seperjuangan Mahasiswa Biologi ITS angkatan 2012 (B15), dan seluruh pihak yang telah memberikan doa, bantuan, dan semangat.

\section{DAFTAR PUSTAKA}

[1] N. K. D. Zakaria, "Pengaruh ekstrak ikan gabus (Channa striata) terhadap penyembuhan luka pasca operasi bedah laparatomi kucing (Felis domestica)," Skripsi, Program Studi Kedokteran Hewan, Fakultas Kedokteran, Universitas Hasanuddin, Makasar (2015)

[2] Fadli, "Bagusnya ikan gabus," Warta Pasar Ikan, Ed. No.86, (2010) 4-5.

[3] Profil Kelautan dan Perikanan Propinsi Jawa Timur untuk Mendukung Industrialisasi KP, Pusat Data Statistik dan Informasi Sekretariat Jendral KKP (2013).

[4] B. Cahyono, Budidaya Ikan Air Tawar, Cetakan Kelima. Kanisius (2005).

[5] Winaruddin dan Eliawardani, "Inventarisasi ektoparasit yang menyerang ikan mas yang dibudidaya dalam jaring apung di 
danau laut air tawar Kabupaten Aceh Tengah". Jurnal Kedokteran Hewan, Vol. 1, No. 2 (2007) 66-69.

[6] C. Sommervile. "Parasite of farmed fish," In Biology of farmed fish ed. K. D. Black and A. D. Pickering, Ed. Sheffeild Academic Press (1998) 146-179.

[7] W. M. Lestari, "Identifikasi ektoparasit ikan nila (Orechromis nilaticus Tremavas) pada kolam IPAL (Instalasi Pengolahan Air Limbah) pabrik susu di Jawa Tengah," Skripsi, Program Studi Biologi, Fakultas Sains dan Teknologi, UIN Sunan Kalijaga, Yogyakarta (2015).

[8] A. Umara, M. Bakri, dan M. Hambal, "Identifikasi parasit pada ikan gabus (Channa striata) di Desa Meunasah Manyang Lamlhom Kecamatan Lhoknga Aceh Besar". Jurnal Medika Veterinaria, Vol. 8, No. 2, (Agustus 2014).

[9] E. J. Noga, Fish Disease Diagnosis and Treatment, $2^{\text {nd }}$ ed. USA: Wiley- Balckwell (2010).

[10] F. Gomez dan A. Skovgaard, "The molecular phylogeny of the type-species of Oodinium Chatton, 1912 (dinoflagellata: oodiniaceae), a highly divergent parasitic dinoflagellate with nondinokaryotic characters". Syst Parasitol, Vol. 90 (2015) 125-135.

[11] T. Horiguchi dan S. Otshuka, "Oodinium inlandicum sp. nov. (Blastodiniales, Dinophyta), A new ectoparasitic dinoflagellate infecting a chaetognath, Sagitta crassa". Plankton Biol. Ecol., Vol. 48, No. 2, (2001) 85-95.

[12] J. Lom, "Fish invading dinoflagellates : A synopsis of existing and newly proposed genera". Folia Parasitologica, Vol. 28 (1981) 3-11.

[13] R. Francis-Floyd dan P. Reed, "Ichthyophthirius multifiliis (white spot) infection in fish," Department of Fisheries and Aquatic Science, Florida Cooperative Extension Service, Insitute of Food and Agriculture Science, University of Florida (May 1997).

[14] A. Alminah, "Pengendalian ektoparasit pada benih ikan mas (Cyprinus carpio L.) dengan penambahan garam dapur $(\mathrm{NaCl}) \mathrm{di}$ Balai Benih Perikanan Plalangan Kalisat Kabupaten Jember," Jurusan Biologi, FMIPA, Universitas Jember (2015).

[15] R. M. Duborow, "Protozoan parasites. Southern Regional Aquaculture Center". SRAC Publication, No. 4701 (2003).

[16] Y. Hadiroseyani, P. Hariyadi, dan S. Nuryati, "Inventarisasi parasit lele dumbo (Clarias sp.) di Daerah Bogor". Akuakultur Indonesia, Departemen Budidaya Perikanan, IPB (2006).

[17] I. Fitriliyani, "Pembesaran larva ikan gabus (Channa striata) dan efektifitas induksi hormon gonadotropin untuk pemijahan induk," Tesis, Fakultas Pasca Sarjana, Institut Pertanian Bogor (2005).

[18] M. Syafran, "Biologi reproduksi, makanan, dan pertumbuhan ikan gabus (Channa stiata Bloch) di Daerah Banjiran Sungai Musi Sumatera Selatan," Tesis, Institut Pertanian Bogor (2003).

[19] D. Muthmainah, S. Nurdawati, dan S. Aprianti, "Budidaya ikan gabus (Channa striata) dalam wadah karamba di Rawa Lebak," dalam Prosiding InSINas (2012).

[20] D. J. Marcogliese, dan D. K. Cone, "On the distribution and abundance of eel parasites in Nova Scotia: Influence of $\mathrm{pH}$," $J$. Parasitol., Vol. 82 (1996) 389-399.

[21] J. P. Carney dan T. A. Dick, "Helminth communities of yellow perch (Perca flavescens (Mitchill): Determinants of pattern," Can. J. Zool., Vol. 78 (2000) 538-555.

[22] A. Halmetoja, E. T. Valtonen, dan E. Koskenniemi, "Perch (Perca fluviatilis L.) parasites reflect ecosystem conditions: A comparison of a natural lake and two acidic reservoirs in Finland," Int. J. Parasitol., Vol. 30 (2000) $1437-$ 1444 .

[23] C. P. Goater, R. E. Baldwin, dan G. J. Scrimgeour, "Physicochemical determinants of helminth component community structure in whitefish (Coregonus clupeaformes) from Adjacent Lakes in Northern Alberta, Canada," Parasitology, Vol. 131 (2005) 713-722.

[24] A. Karvonen, K. K. Bjarni, Sk. U. Skuli, L. Maiju, R. Christian, dan J. Jukka, "Water temperature, not fish morph, determines parasite infections of sympatric icelandic threespine sticklebacks
(Gasterosteus aculeatus)," Ecology and Evolution, Vol. 3, No. 6 (2013) 1507-1517.

[25] G. L. Hoffman, Parasites of North American freshwater fishes, Berkeley and Los Angeles: University of California Press (1967) 486.

[26] A. T. A. Ahmed, "Morphology and life history of Trichodina reticulate from goldfish," Fish Pathology, Vol. 12, No. 1 (1977) 21-31.

[27] M. Alifuddin, Y. Hadiroseyani, dan I. Ohoiulun, "Parasit pada ikan hias air tawar (ikan cupang, gapi rainbow)," Jurnal, Vol. 2, No. 2 (2003) 93-100.

[28] J. E. H. Patterson dan K. E. Ruchstuhl, "Parasite infection and host group size: A meta-analytical review," Parasitology, Vol. 140 (2013) 803-813.

[29] Zulmarham, "Intensitas parasit Trichodina sp. yang menginfeksi ikan nila (Oreochromis nilotica) pada ukuran yang berbeda," Skripsi, Fakultas Ilmu, Ilmu Pertanian (2011).

[30] S. K. Ali, Y. Koniyo, dan Mulis, "Identifikasi ektoparasit pada ikan nila (O. nilotica) di Danau Limboto Provinsi Gorontalo," (2013).

[31] Majumder, S., Somerita P., Bandyopadhyay, P.K. 2015. "Effect of Temperature on the Prevalence of Different Parasites in Cirrhinus mrigala Hamilton of West Bengal". Parasitology Laboratory, Department of Zoology,University of Kalyani, Kalyani, West Bengal, India.J Parasit Dis (Jan-Mar 2015) 39(1):110-112.

[32] L. S. Sarjito dan A. H. C. Haditomo, "Identifikasi ektoparasit pada kepiting bakau (Scylla serrata) yang dibudidayakan di Tambak Pesisir Pemalang," Journal of Aquaculture Management and Technology, Vol. 3, No. 3, (2014).

[33] J. Talunga, "Tingkat infeksi dan patologi parasit Monogenea (Cleidodistus sp.) pada insang ikan patin (Pangasius sp.)," Skripsi, Program Studi Budidaya Perairan, Jurusan Perikanan, Fakultas Ilmu Kelautan dan Perikanan, Universitas Hasanuddin Makassar (2007).

[34] E. Yuliartati, "Tingkat serangan ektoparasit pada ikan patin (Pangasius djambal) pada beberapa pembudidaya ikan di Kota Makasar,” FAPERIKA, Universitas Hasanudin (2011).

[35] P. B. Moyle dan Jr. J. J. Cech, Fishes An Introduction to Ichthyology. Upper Saddle River: Prentice Hall (2004).

[36] C. Purbomartono, "Identify of helminth and crustacean ectoparasites on Puntius javanicus fry at Local Hatchery Center Sidabowa and Kutasari," Sains Akuatik, Vol. 10, No.2, (2010) 134-140.

[37] G. Bassleer, Internal Worm Infections. Diseases in Marine Aquarium Fish. Westmeerbeek, Belgium: Bassleer Biofish, Statiostr (1996) 72-75.

[38] G. A. Lewbart, Self-Assessment Colour Review of Ornamamental Fish. U. S.: Manson Publishing, The Veterinary Press (1998).

[39] C. R. Kennedy, Ecological Animal Parasitology. Oxford: Blackwell Scientific Publications (1975).

[40] K. Iriana, R. Gustiano, V. A. Prakoso, dan M. H. F. Ath-thar, Budidaya Ikan Gabus. Bogor: Penebar Swadaya (2016).

[41] H. W. Dickerson, "Ichthyopthirius multifiliis and Cryptocaryon irritans (Phylum Ciliophora)," dalam PTK Woo, $2^{\text {nd }}$ ed. London, UK: Protozoan and Metazoan Infection (2006) 117- 146

[42] G. H. Huwoyon, dan R. Gustiano, "Peningkatan produktivitas budidaya ikan di lahan gambut, Balai Penelitian dan Pengembangan Budidaya Air Tawar," Media Akuakultur, Vol. 8 , No. 1, (2013).

[43] E. W. Taylor, C. A. C. Leite, D. J. McKenzie dan T. Wang, "Control of respiration in fish, amphibians and reptiles," Brazilian Journal of Medical and Biological Research, Vol. 43 (2010) 409 424.

[44] FAO. (2016) River fisher and riverine system. [Online] Available: http://www.fao.org/docrep/003/T0537E/T0537E05.htm 